\title{
MAGISTÉRIO E CONSCIÊNCIA
}

\section{Magisterium and conscience}

\author{
Bernard Sesboüé*
}

RESUMO: Este artigo propõe uma breve reflexão sobre a relação histórica e atual entre o exercício do magistério e o necessário respeito da consciência dos crentes. Uma primeira parte retoma a evolução da consciência a partir dos tempos modernos e de suas consequências : uma nova figura da fé e da vida no seio da comunidade cristã. Uma segunda parte recapitula as diferentes formas de exercício do magistério eclesial no curso da história e as dificuldades postas por seu encontro com a modernidade. $\mathrm{O}$ autor apresenta então um sonho, propondo uma nova maneira de proceder: não mais a simples vigilância, mas a animação de um grande debate planetário sobre todas as dificuldades postas ao ato de crer, a fim de revivificar o sensus fidei do povo cristão. A terceira parte retoma o problema da verdade na qual magistério e consciência moderna devem encontrar um consenso autêntico.

Palavras-Chave: Fé, Magistério, Consciência, Verdade, Mutação.

AвSTRACт: This article proposes a brief reflection on the historical and current relationship between the exercise of the Magisterium and the need to respect the conscience of believers. A first part follows the evolution of conscience from modern times and its consequences: a new figure of faith and of life within the Christian community. A second part recapitulates the different forms of exercise of the ecclesial Magisterium in the course of history and the difficulties posed by its encounter with modernity. The author proposes a dream by proposing a new way to proceed: no longer simply surveillance, but the animation of a large planetary debate about all difficulties made the act of believing, in order to give new life to the sensus fidei of Christian people. The third part takes up the problem of truth in which teaching and modern conscience must find a genuine consensus.

Key words: Faith, Teaching, Conscience, Truth, Mutation. * Professor emérito da Faculdade de Teologia do Centre Sèvres, Paris, França. Artigo
recebido de autor convidado em 05.09.2012 e aprovado para publicação em 28.09.2012. 
$\mathrm{F}_{\mathrm{m}}$ sua brevidade, o liame que o título deste artigo estende entre o ¿magistério da Igreja e a consciência humana põe um problema considerável. O magistério está efetivamente a serviço da expressão da regra da fé, norma que se impõe de maneira obrigatória. A consciência é, no polo oposto, o lugar da liberdade humana fundamental, lugar da autonomia da pessoa, lugar que não pode ser alienado de forma alguma. Mais ainda, a fé cristã segundo a doutrina de são Paulo é libertação do pecado e restauração de uma plena liberdade sob o regime da graça. Como é possível que a norma da fé possa às vezes entrar em conflito com a liberdade do ato de fé e, portanto, com a consciência?

Um outro conceito entra aqui em jogo, o da verdade. A verdade é o objeto de um dever de busca de toda consciência. A verdade é também o que o magistério deve garantir por seu ensinamento e pela vigilância que exerce no âmbito da palavra de fé. A verdade não seria o ponto de convergência, para não dizer de concordância, entre o magistério e a consciência? Passemos então em revista esses três termos chave.

\section{A consciência}

\section{A evolução irreversível da consciência moderna}

Chegamos, sem dúvida, ao fim de um processo, dito da modernidade, que desde o século XVIII desceu lentamente da intelligentsia até os meios populares. Pode-se definir a modernidade, seguindo um artigo clássico de Abel Jeannière ${ }^{1}$, como aquilo que repousa sobre quatro revoluções decisivas dos tempos doravante chamados "modernos": a revolução científica que começa com Newton e rompe com a visão simbólica e tradicional de um universo cheio de significações, para conduzir a um mundo inteiramente matematizável (até a relatividade de Einstein); a revolução política, que fez a humanidade passar da concepção do príncipe cuja autoridade era proveniente de Deus ao ideal da democracia baseada na razão que vê no povo a fonte do poder; a revolução cultural, herdada do Iluminismo, que racionaliza e seculariza os critérios do pensamento, em detrimento de toda tradição recebida; a revolução industrial enfim, que faz o trabalho humano passar do instrumento tradicional à máquina e à máquina-instrumento que permite a produção rápida de todos os bens. Somos todos testemunhas das consequências dessas quatro revoluções em nossa vida social, religiosa e pessoal e dos numerosos problemas engendrados por

${ }^{1}$ JEANNIÈRE, Abel. Q'est-ce que la modernité?. Etudes, Paris, v. 373, n. 5, p. 499-510, nov. 1990 , p. 501 . 
essas mutações, das quais se pode dizer que fizeram a humanidade passar à idade plenamente adulta. Não nos demos ainda, inteiramente, conta das consequências da última revolução, a da informática.

Fala-se, hoje, seguindo a reflexão de Arnold Toynbee, de pós-modernidade, que afeta doravante a mentalidade corrente em todos os países ditos desenvolvidos e progride rapidamente nos países em via de emergência econômica. Um traço característico deste conceito fluido é que a pósmodernidade perdeu as ilusões da modernidade, que via no progresso contínuo da ciência e das técnicas a garantia da felicidade futura da humanidade. Esta desilusão se caracteriza pela perda das ideologias e de um grande número de valores adquiridos, por certo relativismo e um grande individualismo; não só um "desencantamento do mundo", mas ainda um desencantamento do homem a respeito de si mesmo e finalmente a experiência de certo não-sentido (P. Ricœur).

A maioria de nossos contemporâneos acede assim a uma consciência adulta, particularmente suscetível e sensível a valores inteiramente novos: respeito da liberdade do homem; exigência de concertação no exercício da autoridade, suscetibilidade extrema diante de toda exclusão; desejo de ser associado à busca da verdade; rejeição de receber do alto, somente por via da autoridade, afirmações frequentemente incompreendidas.

\section{O nascimento de uma nova figura da fé}

A nova figura da fé nos Tempos modernos é a de uma fé "razoável" e fundamentada, inevitavelmente crítica. Alegramo-nos pelo número crescente de adultos inscritos no catecumentato e pelo fenômeno dos "recomeçantes" ${ }^{2}$. Mas não podemos esconder que esses homens e essas mulheres são portadores desta nova figura da fé particularmente exigente. Doravante, não se nasce mais cristão, mas se torna cristão por uma decisão livre, nos diz K. Rahner ${ }^{3}$, retomando um velho adágio de Tertuliano: nascitur homo, fit christianus. A fé hoje se torna uma fé voluntária, não simplesmente recebida da família. Ela é também uma fé inteligente, que busca compreender o que ela crê, uma fé que quer ser capaz de dar conta de si mesma "de maneira intelectualmente honesta" (K. Rahner). Para isso, ela busca a maior informação possível, exigência que se manifesta pelo gosto dos leigos em estudar a teologia. Esta fé é enfim uma fé comunitária e participante (co-responsabilidade), uma fé notadamente acompanhada pela generosidade e pelo engajamento. Recapitulando todos esses traços: é uma

${ }^{2}$ A França conhece, já há mais de 15 anos, um crescente número de adultos que busca o batismo, sem contar os adultos batizados que voltam à prática religiosa, denominados "recommençants" (nota do tradutor).

${ }^{3}$ RAHNER, Karl. Le courage du théologien. Cerf: Paris, 1975, p. 117. 
fé adulta e refletida, que não quer mais ser tratada à maneira das crianças ou dos adolescentes. Não se está mais no tempo em que os responsáveis pela Igreja podiam dizer a seus fiéis que eles deveriam observar as conclusões de um novo documento oficial, sem ao mesmo tempo aceitar os considerandos. Prescrição e fundamento constituem unidade.

Esta fé espera também um discurso magisterial no qual o tema do convite é anterior ao da obrigação, e ela pretende ser vivida a partir do modelo da comunicação fraterna. Ela quer que seja interpelado seu desejo profundo e que se lhe faça compreender que a mensagem cristã é para o bem e a felicidade do ser humano. Ela está em harmonia espontânea com o esquema escolhido pelo Vaticano II para falar da revelação. Quando Deus se revela, ele se dirige ao ser humano como um amigo fala a um amigo (Ex 33,11), ele instaura um diálogo, uma longa conversação, com a humanida$\mathrm{de}^{4}$. Por exemplo: se o ensinamento da Igreja sobre a moral sexual é tão mal recebido, é certamente em razão de sua exigência, mas é também, em grande parte, porque toma uma forma autoritária e estranha e não chega a ir ao encontro do ponto profundo no qual a experiência humana pode reconhecê-lo como um bem.

Esta nova figura da fé quer viver o "ritual" em comunhão viva com o "existencial". A execução pura do rito sacramental não a satisfaz mais, se este rito não vai ao encontro da experiência da existência humana. É uma nova exigência com relação à liturgia. Esta fé pretende também voltar ao Evangelho, imitar "a maneira de agir do Cristo e dos apóstolos" e se manifestar por certo estilo cristão de vida. A solidariedade do dizer e do fazer, própria à mensagem de Jesus, é frequentemente recordada. É preciso que a pregação transpareça em modo de viver. É preciso que esta nova figura da fé se torne atrativa para os não cristãos e lhes dê o desejo e o gosto de crer. Isso é esperado também do discurso magisterial.

\section{O nascimento de uma nova figura da vida eclesial}

Correlativamente, assistimos à emergência de novas formas de vida comunitária. Falou-se muito das "comunidades de base", mas a exigência comunitária atravessa doravante o conjunto das paróquias. $\mathrm{O}$ tempo do vigário "papa em sua paróquia" pertence ao passado. Os cristãos querem participar da vida paroquial assumindo responsabilidades e suscitando expressões adaptadas da vida cristã. Vemos ao mesmo tempo o crescimento de numerosos grupos de vida evangélica que "transgridem" de alguma forma a fronteira tradicional entre religiosos e leigos. Entre eles se encontram os "movimentos carismáticos", mas eles não são os únicos. Constatamos tam-

${ }^{4}$ Vaticano II, Dei Verbum, n. 2. 
bém o nascimento de movimentos ou de associações de leigos em vista de um apostolado. Existem novas iniciativas caritativas. Redes de vida comunitária se criam por pequenos reagrupamentos. Recolhemos enfim o engajamento de leigos encarregados de pastoral na Igreja ${ }^{5}$. A multiplicidade desses dados, que por sua duração e extensão constituem doravante um "fato de Igreja", é a maneira pela qual o Espírito Santo se dirige hoje às Igrejas.

O mesmo fenômeno se manifesta no nível da diocese, como a experiência dos sínodos diocesanos o mostrou. Ele é esperado, mutatis mutandis, no quadro da igreja universal. A circulação comunitária das energias deve se atualizar igualmente entre Roma e o conjunto das dioceses, com um movimento equilibrado de ida e volta. Se o próprio Deus não temeu entrar em diálogo com a humanidade, por que a autoridade magisterial no exercício de seu papel de regulação da fé não entraria na mesma pedagogia? Esperase que o grande tema da liberdade religiosa, posto em evidência pelo concílio Vaticano II, tenha também um impacto adequado na vida interna da Igreja. Todas essas evoluções são o sinal de uma mudança na sensibilidade comunitária da Igreja. Tal processo não merece ser tomado em conta até nas maneiras de proceder do magistério da Igreja?

\section{O magistério e a regulação da fé}

\section{O magistério eclesial na história}

A função magisterial na Igreja é uma função absolutamente necessária, mas ela é também uma função ingrata, pois consiste não somente em ensinar a mensagem da fé, mas também, e frequentemente, em repreender aqueles/as cujos propósitos ameaçam levar a um desvio na fé. Esta dificuldade foi a de todos os tempos. A história da Igreja está aí para atestar ao mesmo tempo a necessidade da função magisterial e os graves conflitos que ela produziu. Desde o Novo Testamento vemos nascerem inquietudes a propósito dos "pseudoprofetas" ou dos "pseudodidáscalos" (2Pd 2,1; 1 Jo 4,1) ou dos "heterodidáscalos" (1Tm 1,3; 6,3), ou seja das pessoas que ensinam outra coisa que a mensagem apostólica. É preciso então uma vigilância (episkopè) que se exerce acompanhando o anúncio da mensagem cristã e assegurando a guarda do depósito (parathèkè, $1 \mathrm{Tm} 6,20 ; 2 \mathrm{Tm} 1,12.14$ ). No decorrer dos dois primeiros séculos o mesmo fenômeno ganha amplidão.

${ }^{5} \mathrm{Na}$ Igreja francesa essa figura de leigos/as em função pastoral, com um mandato do bispo, tem se difundido muito nos últimos anos (nota do tradutor). 
O cuidado da ortodoxia cresce juntamente com as primeiras heresias. São os bispos que num primeiro tempo assumem o cuidado da "regra de fé": Irineu é um bom exemplo disso. Ele opõe a tradição oficial dos apóstolos às tradições secretas dos gnósticos. Os mesmos critérios se encontram na teologia de Tertuliano. Cipriano será o grande teólogo da cátedra (cathedra) episcopal, onde o bispo forma um com seu povo, enquanto ele pertence in solidum a um mesmo e único episcopado.

O período das grandes heresias trinitárias e cristológicas do século IV ao século IX, quando o Oriente e o Ocidente trabalhavam juntos, dá uma ilustração mais espetacular do conflito entre ortodoxia e heresia. Se o bispo é o grande responsável pela verdadeira fé na sua diocese, a reunião dos bispos se impõe quando um problema de fé ultrapassa o quadro diocesano, como é o caso quando o sentido profundo da regra de fé está em jogo e um debate interno atravessa as Igrejas a ponto de constituir um problema político. A instituição conciliar toma então consciência dela mesma e desenvolve um funcionamento que, de concílio em concílio, faz jurisprudência. Todavia, mais que no período precedente, a complexidade humana e pecadora dos parceiros se manifesta. Nem tudo foi edificante nos concílios antigos. Ario, Nestório, Eutiques e muitos outros manifestaram uma teimosia definitiva diante das decisões conciliares que representavam a fé da Igreja. Mas foram eles sempre tratados no respeito de seus direitos? Não foi o caso entre Cirilo de Alexandria e Nestório em Éfeso. As vicissitudes da reunião de Éfeso (449) foram piores e o papa Leão, o Grande, recusouse em ver um concílio nesse "latrocínio". Gostaríamos que os direitos de cada um fossem perfeitamente respeitados e que o desenvolvimento dos concílios acontecessem na maior serenidade. Não é o caso aqui de refazer a história dos concílios frequentemente dolorosa. Mas sabemos que muitos teólogos buscam hoje reabilitar Nestório. Assim a história nos ensina que um conflito sério na fé sempre é traumatisante e acarreta grandes sofrimentos.

Na Idade Média, e levando em conta aqui apenas o Ocidente europeu, ou seja, um mundo de cristandade, o conflito entre a grande Igreja e a heresia se torna mais rigoroso e se radicaliza na violência. A regulação da fé cristã passou, na Idade Média, pelas horas sombrias da inquisição. Levando em conta costumes ainda brutais e convicções comuns que fazem passar os direitos de Deus antes do respeito da vida humana, é difícil hoje proferir um julgamento equilibrado sobre essa instituição político-religiosa, que foi conduzida ao mesmo tempo pelos papas e pelos reis. Mesmo que nossas referências sejam de outra ordem, não podemos mais aceitar que um santo Tomás justifique a execução de um herético porque este propõe uma falsa moeda de fé e os falsos moedeiros da sociedade civil, naquele tempo, eram executados (S.Th. IIa IIae q. 11, a.3). De fato, no que concerne à inquisição não são apenas os excessos que nos parecem condenáveis, mas o próprio princípio. 


\section{O magistério eclesial em seu encontro com a modernidade}

Com os tempos modernos, a Europa atravessou uma etapa decisiva, e teve a influência do cristianismo teve um grande papel no reconhecimento progressivo dos direitos da pessoa humana e da consciência. A nova figura da fé começa a ver o dia: a obediência pacífica e comunitária dos paroquianos a seus pastores dá lugar à viva consciência de uma experiência de Deus e à angústia existencial da salvação. Os costumes ainda são brutais, as guerras de religião estão aí para confirmar isso, mas a confrontação com a Reforma se dá mais no plano das ideias e passa por um debate teológico. A assunção da subjetividade da fé, ou seja de sua liberdade e de sua sinceridade, vem equilibrar a objetividade de seus conteúdos, referidos segundo as categorias da verdade ou do erro. $\mathrm{O}$ grande debate entre a Reforma e o concílio de Trento modifica os termos que presidem ao julgamento da fé.

No decurso desta longa e profunda mudança da consciência europeia, é difícil não reconhecer que a Igreja católica historicamente reagiu mal às ondas sucessivas da modernidade. Esta atitude é paradoxal, pois a Igreja não parecia reconhecer os frutos lógicos de seu próprio ensinamento. Ela chegou mesmo a faltar a muitos encontros com esta modernidade ${ }^{6}$. Ela considerou a Reforma primeiro como uma desobediência, o que era apenas um aspecto das coisas, sem ver nela a expressão desta incipiente mutação da figura da fé. Ela faltou ao encontro com a virada científica, não somente no caso Galileu, mas também, no âmbito propriamente cristão, no caso do estudo exegético da Bíblia. É suficiente evocar o caso de Bossuet colocando no pilão, em 1678, o livro de Richard Simon, Histoire critique du vieux Testament, após ter lido apenas o índice, porque o livro punha em causa a autenticidade mosaica do Pentateuco. Por causa disso, a exegese católica teve um atraso sensível diante das exegeses protestante e anglicana no decurso dos séculos XVIII e XIX.

No século XIX e durante grande parte do século XX a Igreja católica viveu sob o signo da autoridade. A vigilância magisterial exercida sobre os exegetas, os teólogos e os moralistas se fez de modo arrogante, por intervenções frequentes, a ponto de frear e às vezes mesmo de esterilizar a criatividade teológica. A resposta feita sob o papa Pio $X$ à crise modernista - que era por sinal ela mesma um triste resultado da rejeição católica anterior da pesquisa científica - era sem dúvida necessária no imediato. Ela quis jugular os problemas, mas não lhes aportou a verdadeira resposta. As "questões" doutrinais se sucederam até o Vaticano II. Pensemos, entre muitos outros, nas medidas tomadas em 1950 com relação ao Pe. de Lubac

\footnotetext{
${ }^{6}$ Expliquei-me sobre este tema na obra La théologie au $X X^{\circ}$ siècle et l'avenir de la foi.
} Paris: DDB, 2007, p. 243-289. 
e em 1954 com relação ao Pe. Congar, dois homens reabilitados no Vaticano II e criados em seguida cardeais. Essas reabilitações eram o sinal de uma grave injustiça cometida em relação a eles. O concílio Vaticano II, com o decreto Dignitatis Humanae sobre a liberdade religiosa, permitiu o profundo questionamento de certas teses muito fáceis, sobre as quais a Igreja tinha vivido desde o século XIX. O slogan segundo o qual o erro não tem direito enfim cedeu lugar à afirmação dos direitos e dos deveres da pessoa humana de buscar a verdade em toda liberdade, mesmo se sua consciência errônea. Segundo a doutrina mais tradicional da Igreja, a fé é um ato livre que não pode ser objeto de nenhuma coação nem de nenhuma pressão; a liberdade pertence ao próprio fundamento do ato de fé. O aggiornamento querido por João XXIII começou a operar uma reconciliação entre a Igreja e a modernidade, mas a tarefa está longe de ser concluída. Hoje ainda o observador informado do funcionamento do Vaticano e da consciência comum dos fiéis se inquieta diante da distância imensa que separa essas duas realidade.

Evidentemente é mais fácil dar tal julgamento depois de tudo - com os discernimentos de fundo realizados oficial e culturalmente - , do que no momento em que a mudança das referências adquiridas inquieta as consciências. Não se trata de julgar o passado, mas de tirar dele ensinamentos positivos para o futuro. Diante dessas evoluções, a tarefa do magistério eclesial é cada vez mais angustiante. A figura do mestre e do aluno, com papéis institucionalmente bem distintos, era infinitamente mais confortável.

\section{O magistério se dirige sempre à consciência do ser humano}

A gravidade dos conflitos dogmáticos no decorrer da história e seu caráter frequentemente inexpiável vêm do fato de a consciência estar engajada dos dois lados. Ela é ao mesmo tempo engajada no nível mais elevado, o da relação a Deus, e no nível da interpretação de sua revelação. O Absoluto está em jogo. O magistério é, em consciência, responsável pela ortodoxia da transmissão da fé ; a consciência do fiel está em causa no sim que ele pretende livremente responder a Deus.

Por esta razão a regulação da fé não pode praticamente ser gerada de maneira inteiramente pacífica; seria uma ilusão esperar isso. Seria também muito fácil virar as costas para os parceiros, dizendo que os erros são partilhados ou que esses combates dizem respeito a coisas inúteis como o sexo dos anjos. Os desafios são sempre graves e a responsabilidade do magistério diante da manutenção do "depósito da fé" na sua verdade é terrível. Seus titulares têm um sentido agudo desta responsabilidade para o presente e para o futuro. Esta responsabilidade se revelou neles, às vezes, em comportamentos intransigentes e impacientes. Por outro lado, também os partidários do que se chama "novidades", no sentido pejorativo do termo, agem em nome de sua consciência e devem ser respeitados a esse 
título e considerados no início com um preconceito favorável. Hoje como ontem, podem-se escutar afirmações que contradizem mais ou menos diretamente o Credo cristão. A multiplicação dos meios de comunicação facilita sua difusão. Mais na maioria das vezes as coisas são complexas: o erro pode conter uma parcela de verdade, frequentemente a nova questão surge de um conflito aparente ou real entre a nossa cultura e a da Bíblia ou da tradição antiga. O discernimento demanda tempo. E por cima de tudo, os parceiros são todos homens pecadores. Fatores não doutrinais, como o amor próprio ou os "sentimentos humanos", vêm então interferir.

\section{Eu tenho um sonho}

Sem contradizer a reflexão anterior - não disse eu que não pode haver gestão totalmente pacífica da regulação da fé? -, arrisco algumas proposições que parecerão utópicas com relação ao estado de nosso mundo e da Igreja. O que vou propor será até julgado perigoso, aos olhos de alguns, e insuficiente ou mesmo inútil para os outros, porque supõe o problema resolvido, como se os homens não fossem mais homens. Em meu pensamento, são apenas sugestões de simples sabedoria em vista de um funcionamento, se possível, mais correto da regulação da fé na Igreja e de uma melhor articulação entre o magistério e a consciência, tal como ela é vivida em nosso mundo contemporâneo.

Sei muito bem que hoje são postos em xeque dados fundamentais do cristianismo e que se multiplicam as tentações de dar-lhes uma interpretação que quer respeitar sua intenção com o risco de sacrificar os fatos. Ora, o cristianismo anuncia o fato incrível da intervenção de Deus na história, a fim de nos revelar o desígnio de nossa eleição em Cristo desde antes da fundação do mundo (Ef 1,4). É preciso que alguns fatos venham atestar e inscrever em nossa história este dado maior. $\mathrm{O}$ fato e o sentido são, portanto, solidários. O sentido separado do fato não é o mesmo sentido que o sentido ligado ao fato. Sabemos que muitos dos que se dizem católicos tomaram grande distância das afirmações do Credo.

Essas contestações, às vezes radicais, se inscrevem num tempo em que o tecido comunitário de nossas Igrejas se fragmenta em tendências diversas e às vezes opostas: integristas em ruptura com Roma, tradicionalistas e conservadores de todas as nuanças; fiéis ao aggiornamento proposto pelo Vaticano II e convencidos da urgência ecumênica, mas decepcionados pelo clima atual que parece recuo; progressistas que desejam uma simplificação mais ou menos drástica do Credo; contestadores de muitas exigências morais lembradas recentemente pela Igreja; e certamente outras tendências que esqueço. Do outro lado, não posso ignorar o papel da mídia e seu preconceito frequentemente suspeitoso e crítico com relação à linguagem da Igreja. A mídia exerce, à sua maneira, um verdadeiro "magistério" no nosso mundo pelas posições que toma, autoriza ou desaprova. Ela realiza sem 
dúvida um serviço eminente quando nos informa; mas ela também nos engana, seja por ignorância ou indução coletiva, seja às vezes por intenção deliberada. Nessas condições não é ilusório esperar um retorno a um consenso fundamental nas coisas da fé? Enfim, tendo em vista o comportamento tradicional e sempre atual do magistério da Igreja, é permitido esperar de sua parte a audácia de entrar no movimento aqui sugerido?

Sempre é permitido esperar. Meu sonho se inscreve na dinâmica inaugurada pelo Vaticano II, o concílio do diálogo, cujo cinquentenário celebramos. Gostaria que o magistério eclesial, ou seja, o papa e os bispos, possa se liberar da figura dominante da vigilância ${ }^{7}$ que é a sua, para voltar à da animação. O exercício do magistério hoje não pode se contentar de cuidar em reagir aos erros. Ele deve responder às múltiplas questões que a modernidade e a pós-modernidade põem à fé; e para isso, precisa engajar progressivamente um grande diálogo e um debate prolongado com a comunidade cristã planetária, organizando as questões de maneira precisa. Este diálogo da Igreja se dirigiria ao sensus fidei que habita a consciência cristã. Alguns poderão evidentemente me objetar que este diálogo só encontrará uma opinião pública "sob influência", e que esta só proporá soluções fáceis conformes ao ar do tempo e ignorantes dos desafios da fé. A reação primeira será talvez desta ordem. Mas o papa Pio XII, não tinha falado, com bastante respeito, de uma opinião pública na Igreja? A aposta consistiria em esperar que a seriedade dos debates possa despertar o autêntico sensus fidei que habita a consciência cristã e provocar uma reflexão positiva que faria redescobrir o sentido e o valor dos pontos maiores da fé. Seria uma aposta no Espírito Santo. O magistério teria sob sua responsabilidade aportar respostas credíveis, mostrando seu fundamento nas Escrituras e na tradição, elaborar sua formulação numa linguagem não somente compreensível, mas também falante e sugestiva para nosso tempo. Não é suficiente repetir a doutrina, é necessário compreender seu sentido profundo e sua motivação, mostrar em que ela é portadora da verdade do ser humano e que ela é ordenada à sua felicidade. "O magistério deve, por sua missão mesma, dizia outrora G. Dejaifve, dialogar com o povo cristão e não ter um monólogo estéril que se contentaria de se repetir sem se encontrar com as dificuldades e as aporias que os fiéis levantam no exercício de sua vida cristã e de seu apostolado" ${ }^{8}$.

Sonho então ver se colocar em caminho uma imensa circulação de energias da fé permeando o conjunto do povo de Deus, numa vasta cooperação e uma série de intercâmbios construtivos, graças aos quais o duplo movimento que vai da cabeça aos membros e sobe dos membros à cabeça seria

\footnotetext{
${ }^{7} \mathrm{O}$ que não quer dizer abandoná-la totalmente.

${ }^{8}$ DEJAIFVE, Georges. Où en est le problème de l'infaillibilité?, N.R.Th, Bruxelles, v. 100 , n. 3 , p. $372-387$, mai/jui 1978 , p. 386 .
} 
honrado e respeitado. É preciso que as questões sejam postas e expressas até seu fundo e que as respostas as tenham cada vez mais em conta. A autoridade doutrinal do magistério sendo salva, isso não quer dizer que o intercâmbio das questões e das respostas permaneceria unilateral. O próprio magistério deve levar em conta a dificuldade de crer que atinge os crentes, seja em geral, seja concernente a diversos pontos particulares. É preciso que passemos de um silêncio distante, sinal de desinteresse ou de desacordo surdo da parte do povo de Deus, ao engajamento interessado de cada um numa palavra respeitosa da fé, sem dúvida, mas também audaciosa. É preciso que a recepção tenha o lugar que lhe compete ao lado da tradição. Um dos danos mais graves que conhece nossa Igreja é o esquecimento da recepção viva e calorosa dos fieis à fé transmitida.

Parece-me que tal iniciativa seria a única forma de responder às exigências da nova figura da fé descrita acima - fé adulta, fé motivada e engajada e de respeitar a consciência dos fiéis. Esta figura da fé e da consciência é, por sinal, incontornável, mesmo nas novas Igrejas. Os cristãos devem ser tratados como adultos, com maioridade cidadã na Igreja. Tratar-se-ia de uma grande audácia, que só pode, uma vez mais, ser permitida pela confiança na presença do Espírito Santo no povo cristão. Será incontestavelmente difícil, mas eu não vejo que se possa fazer a economia disso. Poderse-ia dizer também que se trataria de um período de grande catequese, mas de uma catequese na qual os catequizados seriam parte implicada da formulação das coisas. Fala-se hoje muito de "nova evangelização": se esta não quer permanecer no âmbito das boas intenções, é esta a forma que ela deve tomar. Não se pode esquecer tampouco a dimensão ecumênica das coisas.

Será necessário, sem dúvida, começar pelo primeiro artigo do Credo e voltar ao problema fundamental de Deus, falar do mistério do Cristo, Filho e Verbo de Deus, do Espírito Santo e da Igreja, que se encontra confrontada hoje a múltiplos problemas. Não se poderão evitar os novos problemas da sociedade e da ética.

Num tal empreendimento, se o impulso inicial só pode vir de Roma, será necessário dar um grande lugar à colegialidade dos bispos e das Igrejas. Muitos observaram que, desde o concílio Vaticano II e apesar do questionamento da colegialidade episcopal, a regulação da fé continua a se fazer hoje quase que exclusivamente pela via romana. $\mathrm{O}$ cardeal Walter Kasper, após vários outros, se emocionou, lamentando-se que numerosas possibilidades não tenham sido inventariadas. Sei que nos meios romanos alguns estimam que os bispos não são "fiáveis", porque se tornaram muito sensíveis às campanhas de opinião. Mas não é fazendo-os participar da elaboração dos julgamentos doutrinais que se pode ajudá-los a tomar uma consciência viva de sua responsabilidade com relação a toda a Igreja? Não é pedindo-lhes de ser porta vozes dos problemas de seus fiéis que se 
aprofundará o consenso da fé? Isso, por sinal, se verificou duas vezes, quando Pio IX, primeiro, antes de 1854, e Pio XII em seguida, antes de 1950, consultaram todos os bispos sobre os dois dogmas relacionados à Virgem Maria, o dogma da Imaculada Conceição e o dogma da Assunção. Eles colocaram ao conjunto do colégio episcopal duas questões: 1. Este dogma é definível?; 2. É oportuno defini-lo? Durante um tempo suficiente os bispos consultaram por sua vez suas faculdades de teologia e seus seminários maiores. Um debate se instaurou e do qual muitos católicos puderam tomar parte. Não há nesses casos um belo exemplo, que infelizmente não conheceu algo equivalente após o Concílio Vaticano II? Certamente este procedimento pode se fazer fora do caso de uma definição dogmática. Não se pode excluir tampouco, no caso de tal empreendimento, a convocação de um novo concílio, segundo formas adaptadas ao grande número atual de bispos.

Na mesma lógica é preciso, também, ir mais longe e colocar em ação o princípio da comunidade, que pertence à estrutura da Igreja com o princípio da colegialidade e o da presidência. Será necessário dirigir-se ao "sensus fidei" do povo de Deus, segundo o sentimento do Concílio Vaticano II: “O conjunto dos fieis, ungidos que são pela unção do Santo (cf. 1 Jo 2,20 e 27), não pode enganar-se no ato de fé, e manifesta esta sua peculiar propriedade mediante o senso sobrenatural da fé de todo o povo quando, 'desde os Bispos até os últimos dos fieis leigos' (Santo Agostinho), apresenta um consenso universal sobre questões de fé e costumes" (LG n. 12 § 1). Este texto dogmático é extremamente importante. Ele concerne evidentemente à Igreja em sua totalidade, que une os membros da hierarquia e os fiéis.

Ainda uma vez, antecipo a multiplicidade de objeções que surgem: Você quer fazer da opinião pública na Igreja a regra da fé. Respondo: Seria uma catástrofe. Tratar-se-ia, antes, de convidar a opinião pública a se converter e a retomar consciência de suas responsabilidades, pois esse exame de consciência sobre as coisas da fé, com os debates que ele produziria, poderia ser extremamente benéfico. - Você quer instaurar a democracia na Igreja, mas esta não é uma democracia. Respondo: Isso é certamente verdadeiro, mas ela não é tampouco uma monarquia, nem uma oligarquia. O "depósito da fé" foi confiado a um povo. O sujeito primeiro da infalibilidade da Igreja é o povo cristão inteiro, estruturado, sem dúvida, e no qual a hierarquia tem um papel a desempenhar. Por que não admitir, na Igreja, o debate antes de uma decisão importante? Seria convidar as comunidades cristãs à reflexão e à responsabilidade. Verdadeiros debates poderiam fazê-las sair da opinião imediata e superficial. Seria um exercício de corresponsabilidade, que faria circular em toda a Igreja as energias da fé, segundo o movimento descendente e ascendente, mas também segundo o movimento de intercâmbios fraternos entre Igrejas muito diferentes. Após esse debate, a consciência do povo cristão, melhor informada, poderia aderir de maneira mais ativa ao ensinamento magisterial. 
Outra maneira de integrar o povo de Deus na tarefa de regulação da fé, seria pôr em jogo o critério da recepção. Esta está na ordem do dia, nesses anos em que celebramos os cinquenta anos do Vaticano II. A recepção é um fenômeno original que se constata após o ocorrido. Ela não é de ordem jurídica. Ela diz, geralmente após várias gerações, o que foi concretamente integrado em sua vida pelo povo cristão. Ela é a expressão da infalibilidade da Igreja, porque ela não é manipulável por ninguém. Não seria um bom exercício repertoriar o que foi efetivamente recebido do Vaticano II, mesmo se a recepção deste concílio não se completou ainda?

Tal debate mostraria também, para as novas questões postas, que a Igreja não tem respostas imediatas a tudo. Ela não é uma máquina de distribuição de julgamentos ou de respostas rápidas, cada vez que um novo problema, geralmente de ordem ética e oriundo da pesquisa científica, se põe. Até uma época recente, uma nova descoberta não punha problema moral: ela podia ser utilizada logo em seguida. Hoje não é mais assim. A humanidade acede a possibilidades de manipulações sobre si mesma que podem contradizer sua vocação profunda. Ela não pode, portanto, assumir imediatamente tal descoberta. Mas é normal que um tempo de interrogação preceda uma decisão e permita a maturação de uma resposta, antes da qual uma larga consulta deverá ter lugar.

\section{Uma relação cristã com a verdade}

Para além de todos os procedimentos ou maneiras de fazer as coisas, existe um ponto de reconciliação e de unidade que deveria contribuir a tornar parceiros, numa busca comum da verdade, os que se opunham ontem ou se opõem ainda hoje. Entendo aqui a verdade que se recapitula na pessoa de Jesus, o Cristo, que diz: "Eu sou o caminho, a verdade e a vida" (Jo 14,6). O laço entre essas três palavras é pleno de sentido. Ele exprime uma solidariedade e mesmo uma circumincessão entre eles. Ele significa que a verdade é uma via por onde se caminha e se progride, que a verdade é sempre algo a se fazer, segundo o termo de João (Jo 3,21). A verdade não é estática: ela é movimento rumo a um "sempre mais". Quando se diz "basta", estamos perdidos. A única relação que podemos ter com a verdade é, portanto, a de buscá-la sem cessar.

Mas, dir-se-á, o mistério cristão, recapitulado em nosso Credo, é bem conhecido. Vivemos do adquirido da revelação judeu-cristã, definitivamente realizada na pessoa de Jesus Cristo. Certamente, recebemos a mensagem essencial e definitiva que nos traz a salvação. Mas se a revelação é terminada com o desaparecimento da geração dos apóstolos, ela não o é do lado dos que a recebem. Não terminamos nunca de descobrir a verdade do Evangelho. Isso é verdade para cada um de nós, no decurso de nossa 
existência, onde chegamos a evangelizar cada vez mais regiões de nosso ser permanecidas por muito tempo pagãs. Isso é verdade para o corpo inteiro da Igreja, como o mostra a história de 2000 mil anos de cristianismo. De idade em idade, homens e mulheres meditaram a Palavra inesgotável de Deus, perscrutando-a e escrevendo sobre ele. Eles cruzaram os conhecimentos vindos da fé com os que descobriram sem cessar sobre o mundo, a natureza e o ser humano. Da mesma forma, cristãos perceberam novas exigências do Evangelho, a fim de colocá-las em ação. Vivemos da Palavra de Deus original, mas da Palavra que foi sem cessar transmitida, interpretada e atualizada.

Jesus dizia também: "Eu sou a verdade e a vida". A verdade é uma pessoa viva, e a mensagem que ela entrega é a vida. A verdade que Jesus proclama ser em sua pessoa de Filho encarnado é ela mesma uma verdade para sempre viva, uma verdade fonte de vida e ordenada à "vida eterna", uma verdade que é ressuscitada e nos fará ressuscitar. A vida não para nunca. Não somente esta verdade é sempre a fazer, mas ainda ela tem algo a nos revelar das riquezas insuspeitadas sobre nossa vida humana, por pouco que aceitemos considerá-la como futuro. O que se chamou de "virada antropológica" do século XX não terminou ainda. Isso foi expresso assim pelo Vaticano II: "Na verdade o mistério do ser humano só se esclarece verdadeiramente no mistério do Verbo encarnado. [...] Novo adão, o Cristo, na revelação mesma do mistério do Pai e de seu amor, manifesta plenamente o homem a ele mesmo e lhe descobre a sublimidade de sua vocação" (GS, n. 22, § 1). Temos sempre que nos lembrar que a revelação de Deus ao ser humano, não é somente uma revelação de Deus sobre Deus, mas uma revelação de Deus sobre o ser humano.

No domínio da verdade somos então convidados a uma grande humildade. Esta humildade cristã diante do mistério insondável de Deus e de seu desígnio corresponde, por sinal, a nossa maneira contemporânea de nos relacionar com a verdade. Esta não é algo que se possui uma vez por todas. Ela nos encerra de todos os lados; ela resta para sempre além de nós, ela nos transcende. É ela que deve nos possuir.

Não é possível que esta tomada de consciência não incida sobre a maneira de a Igreja exercer a regulação da fé. Isso requer uma imensa humildade de todos. Humildade do povo cristão em sua maneira de acolher e de receber o ensinamento do Evangelho, transmitido e concretizado pela Igreja no decorrer da história, que nos atinge hoje através de uma longa cadeia de testemunhas. Podemos ser agradecidos ao magistério da Igreja por ter assumido com sucesso este grande desafio da transmissão da fé. Ele o fez com todo o peso que isso implicou, mas isso é a consequência do princípio da encarnação: não somente o Filho se fez um homem autêntico, mas ele ainda confiou sua Igreja a homens pecadores. Humildade do magistério, também, diante da grandeza da mensagem sempre nova a ser transmitida 
e do respeito, em seus fiéis, das exigências da fé divina, que não deveria em nada ser sobrecarregada de elementos adventícios.

O conflito sempre possível entre o magistério e a consciência do fiel - e em particular do teólogo - só pode ser gerenciado de maneira construtiva se os dois parceiros aceitarem dar a prioridade absoluta à verdade, que cada um busca, mas numa posição diferente. A responsabilidade do magistério é a da guarda do depósito, mas sua tentação é a de uma segurança exagerada. O desafio de sua conduta é de sustentar ao mesmo tempo o duplo respeito da verdade e da consciência de seu parceiro. Quanto à pessoa em causa, ela é convidada a por a busca da verdade no primeiro plano de suas preocupações, num sentido igualmente grande de sua própria responsabilidade.

Tradução: Geraldo Luiz De Mori

Bernard Sesboüé, religioso jesuíta. Tem licenciatura em letras clássicas, obtendo o diploma de estudos superiores em filosofia (Sorbonne); doutor em teologia na Universidade Gregoriana, 1979, com a tese Traduction et analyse théologique de l'Apologie d'Eunome de Cyzique et du Contre Eunome de Basile de Césarée. Professor emérito pela Faculdade de Teologia do Centre Sèvres, Paris, França. Foi professor na Faculdade de Teologia Jesuíta de Lyon-Fourvière, França. Tem 388 títulos publicados cujas referências se encontram no livro Sauvés par la grâce, Editions facultés jésuites de Paris, 2009.

Endereço: 42 rue de Grenelle

75343 Paris, Cedex 07 France 